\title{
要介護老年者の医学的総合機能評価 ーレーダーチャート方式採用と解析の試み一
}

\author{
峯廻 攻守 加藤 隆正
}

\begin{abstract}
〈要 約〉 要介護老年者の医学的総合機能評価とその結果を医療スタッフ全員が容易に理解し, 把握でき る事を目的にレーダーチャート方式による医学的総合機能評価を試みた。更に評価に用いた各指標を統計学 的に検討し，主要診断別の病態・機能の特色を明らかにするべく試みた。対象は，1997年 5 月時，当科入院 中の50例（男性12例，女性38例，年齢73 101歳，平均85 55.4歳）を対象とし，主要診断名，精神機能，身 体機能，栄養，全身合併症，冠危険因子，社会背景のデーターベースを作成し，最終的に主要診断名以外の 各因子をスコア化したものでレーダーチャートを作成した．その結果，（1）本法は老年者個々人の全体像を 医療スタッフ全員が容易に理解し把握するのに有用であると同時に, 各主要診断別病態の特色をパターンで 認識するためにも有用と思われた。（2）脳血管障害群では精神，身体，栄養の三指標間相互に有意の正相関 を認め, 治療, 看護, リハビリ等のケアプラン作成上，これら三つの指標に対して，より総合的に戦略を立 てる必要性のある事が示唆された。（3）一方アルッハイマー型痴呆群では身体, 栄養の二指標間に正相関を 認めるのみで, 精神機能との関連では唯一罹病期間との間に有意の負の相関を認めた. 即ち本症では, 精神 機能と罹病期間の関係を念頭に，その QOL に重点を置いたケアプラン作成が重要課題と思われる. (4) 後 期老年者あるいは超老年者においては, 身体, 精神機能に対するケアと同等かそれ以上に, 栄養学的評価と それに基づく栄養ケアの重要性が示唆された.
\end{abstract}

Key words : 医学的総合機能評価, レーダーチャート, 脳血管疾患, アルッハイマー型痴朵, 栄養学的ケア

（日老医誌 $1999 ； 36 ： 206-212$ )

\section{緒 言}

高齢社会を迎えて，老年者の医療で最も問題となるの は，慢性疾患により自立した生活が出来なくなることで ある。 それは脳卒中に代表される身体的要因によること もあり, 痴呆に代表される精神疾患に由来することもあ る.あるいはまた，一人暮らしに代表されるような社会 環境因子が関与することも大きい.このように自立を妨 げる要因を多角的に解析し, 生活機能を改善することが, 老年者医療の最大の課題と考えられる. それは検査, 診 断, 治療という一般的病院の医療の流れの中では解決で きず，医師はもとより看護，介護，栄養，リハビリ，ケー スワーク職を含めた密接な診療協力体制が必要な多角的 チーム医療であり，地域医療でもある．老年者の医学的 総合機能評価は, comprehensive geriatric assessment (以下 CGA)の日本訳である ${ }^{122)}$. 当院でも過去, resident assessment instrumentによる minimum data set（以下 MDS）を採用し ${ }^{3)}$ ，評価とケアプランの作成を実践して きた歴史を有しているが，ともすれば，看護・介護とそ

Y. Minemawari, T. Kato：医療法人溪仁会西円山病院内 科

受付日：1998. 8.17, 採用日：1998.10.28
のケアプラン作成のみに限局化された面が先行する嫌い があった。これに対して臨床医はどのようにケアの質を サポートし，予後の把握のために取り組むべきであろう か. その第一段階として, 医師の視点から医学的病態の 把握をも考慮に入れた CGA 作成が，アプローチの有力 な手段になると考え，医療スタッフ全員が，容易に個別 の症例の総合機能を理解し, 共有できる事を目的に,レー ダーチャート方式による病態機能評価を試みた.

\section{方 法}

対象は当科に 1997 年 5 月時入院の50例（男性12例，女 性38例で，年齢73歳～101歳，平均 $85 \pm 5.4$ 歳）である. 各症例について主要診断名, 知的機能 (Mental), 日常 生活身体機能 (ADL), 栄養 (Nutrition), 合併症 (Complication), 動脈硬化症のリスクファクター（Risk Factor), 社会背景（Social）に関するデーターベースを作 成し, 最終的に主要診断名以外の各因子をスコア化し, レーダーチャートを作成. 要介護老年者の持つ機能評価 に病態の要素を加味し, 視覚的に全体像が把握されるよ うにした. 主要診断に関しては, 老年者の場合, 生活障 害の要因が多岐にわたり，そのため特定が困難な例もあ り得るが, 要介護となるきっかけとして一番重大な因子 
であると思われるもののみを主要診断とし，その他のも のは病歴を理解する意味も含めて, 慢性化した既往歴 共々合併症の項目に入れた。

現在日本人の死因は癌死を除くと, 第 1 位から 3 位ま でのうち, 約 6 割は心臟, 脳の血管障害による「血管死」 ともいうべき現状を念頭に，動脈硬化症の危険因子，お よび激増しつつある耐糖能障害の状況を把握し, 併せて 薬物療法の介入も, それら危険因子との絡みで必要最小 限度のものは, データーベースに含めることとし, 血液, 尿の検査成績も全身スクリーニングに最低限必要なもの のみを含めた。知的機能評価は, 改訂長谷川式簡易知能 評価スケール（HDS-R）を用いた4). ADL 自立度はバー セル指数を用いた . 栄養の指標としては血清アルブミ ン值を用い，<3.5, 3.5〜3.7, 3.8〜 4.0, 4.1 4.3, >4.3の 5 段階に分け，それぞれ $20,40,60,80,100$ のスコアとした. 合併症については一般内科成書の領域分類を基準とし, 18の領域 (脳神経系, 心血管系, 消化器系, 呼吸器系, 腎・泌尿器系, 婦人科系, 眼科系, 耳鼻科系, 歯科系, 皮虐科系, 骨・筋肉系, 神経精神系, 血液系, 内分泌系, 代謝系，アレルギー性疾患，中毒疾患，その他)に分類.
合併症の重症度の重みづけは敢えてせず，合併症無しを 100 とし，一合併症増加するごとに5.5を減じた．動脈硬 化の危険因子(高血圧, 糖尿病, 高脂血症, 喫煙, 肥満, 高尿酸血症）についても同様に，危険因子無しを100と し，一個増えるごとに16.6を減じる方式にてスコア化を 試みた。社会的環境評価は，奥川らによるものを参考に しだ). 評価項目は, 同居の配偶者の有無, Key Person の有無, マネージメントに携わる人, 経済的援助者, ケ アに携わる人，心の拠になる人，医療機関受診の際の移 動の 7 項目である. 前二項目については有, 無をそれぞ れ 1,0 とし, 後五項目は無しを 0 , 普通 1 , 良を 2 とし, 総合点は $0 \sim 12$ 点でスコア化した。これら社会的環境の 量や質に関する定量化の試みは，必ずしも客観的尺度と して検証されたものではないが,まずスコア化を試みて， 評価の一指標とした. 各因子のスコアは, 医師以外の医 療スタッフが, 病態, 状態像を把握しやすいように100 点満点に換算し, 単位は全て\%表示としたもので, レー ダーチャートを作成すると同時に統計処理上もその数值 を用いた。なお，統計処理は $\chi^{2}$ 検定，Student-t 検定を 用いた。

\section{Cerebrovascular Disease}

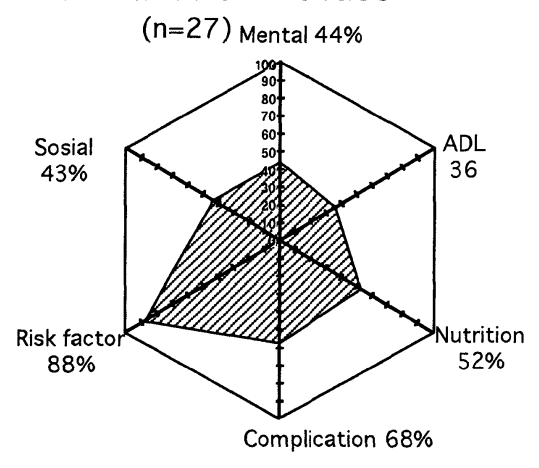

\section{Bone Fracture}

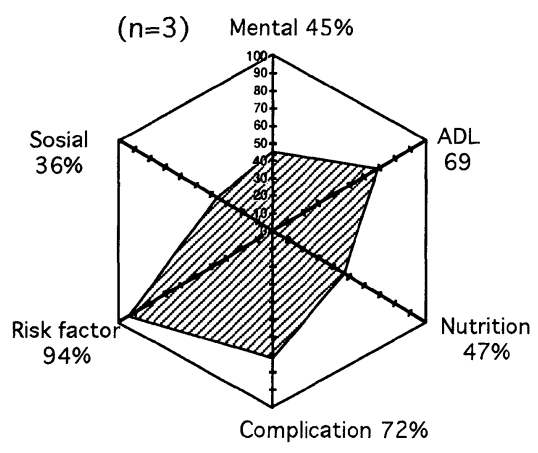

Alzheimer's Disease $(n=12)$

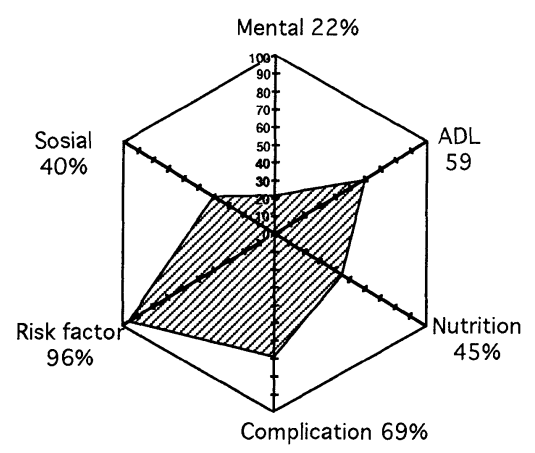

Rheumatic Arthritis

$(n=3)$

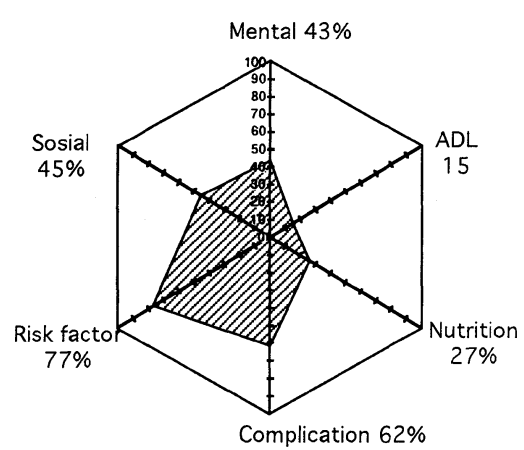

Parkinson's Disease

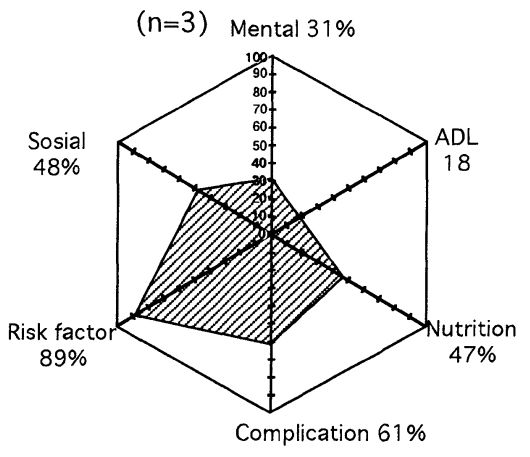

Dead

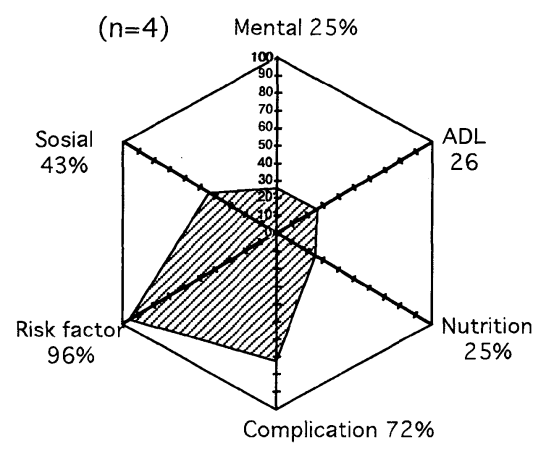

Fig. 1 Radar charts of Patients with Cerebrovascular Disease, Alzheimer's Disease and Other Disease 


\section{成 績}

1）主要診断別レーダーチャート（Fig. 1)

前述のデーターベースを基に最終的に呈示されるレー ダーチャートである．各々の指標の各頂点が，病態的に も生活の自立度も最も理想的な状態であり, 中心部に偏 位するほど，病態的にも生活自立度もより重症であるこ とを示す．図は疾患別のレーダーチャートで，上段左よ り脳血管性疾患 (CVD), アルツハイマー型痴呆 (AD), パーキンソン病 $(\mathrm{PD})$ ，下段左より骨折 $(\mathrm{BF})$ ，慢性関
節リウマチ（RA），および本調査実施後 6 ケ月以内の死 亡群（Dead）を示す。現在我々は病棟でのケースカン ファレンスにおいて各症例のレーダーチャートを呈示 し，情報の共有化とケアプラン作成の一助として使用し ている.

2）主要診断別臨床特性（Table 1)

比較的症例数の得られた CVD, $\mathrm{AD}$ 両群の比較では, CVD は ADに比し, 罹病期間が有意に長く, ADL は有 意に低かったが，他方 HDS-R は有意に高值を示した.

3）知的能力と身体能力の関係（Fig. 2)

Table 1 Clinical Characteristics of Patients With Cerebrovascular Disease, Alzheimer's Disease and other Diseases

\begin{tabular}{l|r|r|r|r|r}
\hline & $\begin{array}{c}\mathrm{CVD} \\
(\mathrm{n}=27)\end{array}$ & $\begin{array}{c}\mathrm{AD} \\
(\mathrm{n}=12)\end{array}$ & $\begin{array}{c}\mathrm{PD} \\
(\mathrm{n}=3)\end{array}$ & $\begin{array}{c}\mathrm{BF} \\
(\mathrm{n}=3)\end{array}$ & $\begin{array}{c}\mathrm{RA} \\
(\mathrm{n}=3)\end{array}$ \\
\hline Sex (Male/Female) & $4 / 23$ & $8 / 4$ & $0 / 3$ & $0 / 3$ & $0 / 3$ \\
\hline \multicolumn{5}{|c|}{ mean (SD) } \\
\hline Age (years old) & $84(8)$ & $82(6)$ & $76(2)$ & $92(6)$ & $92(5)$ \\
Body Mass Index & $19(4)$ & $17(4)$ & $15(1)$ & $18(2)$ & $18(5)$ \\
Duration of Mordify (months) & $* * 85(70)$ & $47(28)$ & $122(117)$ & $45(40)$ & $164(129)$ \\
Hemoglobin(g/dl) & $12.2(1.6)$ & $11.9(1.7)$ & $12.2(0.5)$ & $12.2(1.9)$ & $9.3(2.4)$ \\
Serum Albumin (g/d $l)$ & $3.6(0.7)$ & $3.7(0.4)$ & $3.8(0.1)$ & $3.6(0.9)$ & $3.2(0.4)$ \\
Creatinin Clearance(ml/min) & $110(35.9)$ & $98(39)$ & $100(32)$ & $136(19)$ & $84(10)$ \\
Hasegawa's Dementia Scale(\%) & $* * 44(33)$ & $22(19)$ & $31(27)$ & $45(29)$ & $43(9)$ \\
Activity of Daliy Living(\%) & $* 36(32)$ & $59(38)$ & $18(29)$ & $69(54)$ & $15(5)$ \\
Nutritional State(\%) & $52(29)$ & $45(15)$ & $47(12)$ & $47(46)$ & $27(12)$ \\
Complication(\%) & $68(7)$ & $69(6)$ & $61(6)$ & $72(6)$ & $62(6)$ \\
Risk Factor(\%) & $88(10)$ & $98(8)$ & $89(10)$ & $94(10)$ & $77(10)$ \\
Social State(\%) & $43(10)$ & $40(8)$ & $48(14)$ & $36(0)$ & $45(0)$ \\
\hline
\end{tabular}

$*<0.05 \quad \mathrm{CVD}$ vs $\mathrm{AD} \quad * *<0.01 \quad \mathrm{CVD}$ vs $\mathrm{AD}$

CVD : Cerebrovascular Disease AD : Alzheimer's Disease PD : Parkinson's Disease $\mathrm{BF}$ : Bone Fracture RA : Rheumatic Arthritis

O CDV $(n=26 r=0.6936 p<0.001)$ $\oplus$ Dead

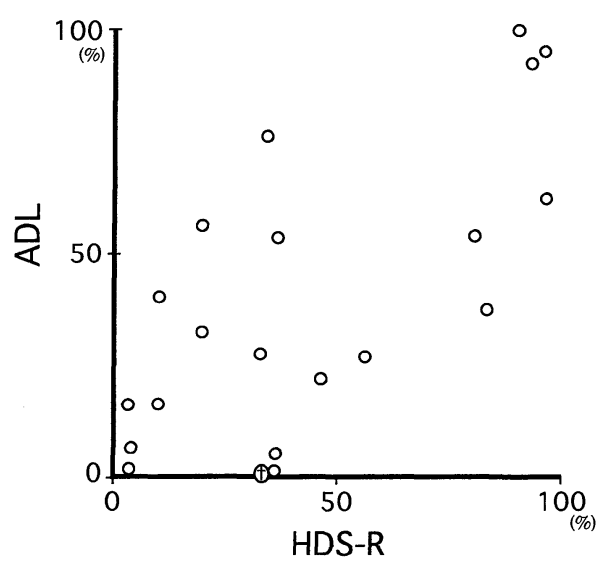

AD $\quad(n=11 \quad r=0.567 \quad 0.05<p<0.1)$ $\oplus$ Dead

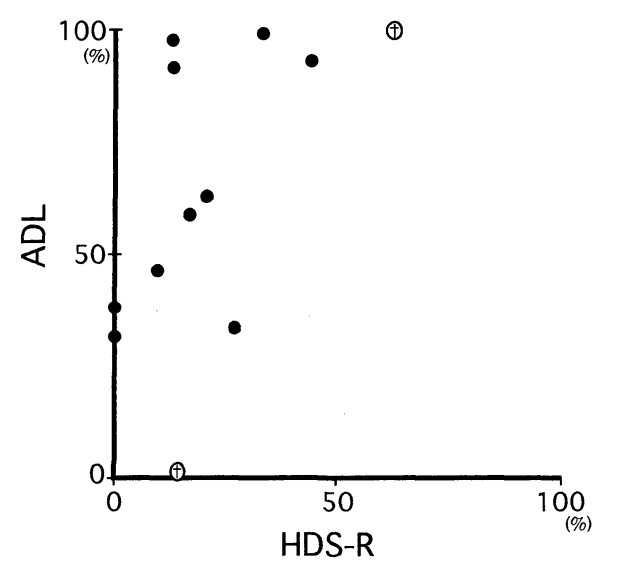

Fig. 2 Relations between Hasegawa's Dementia Scale (HDS-R) and Activity of Daily Living (ADL) in Patients with Cerebrovascular Disease (CVD) or Alzeimer's Disease (AD) 

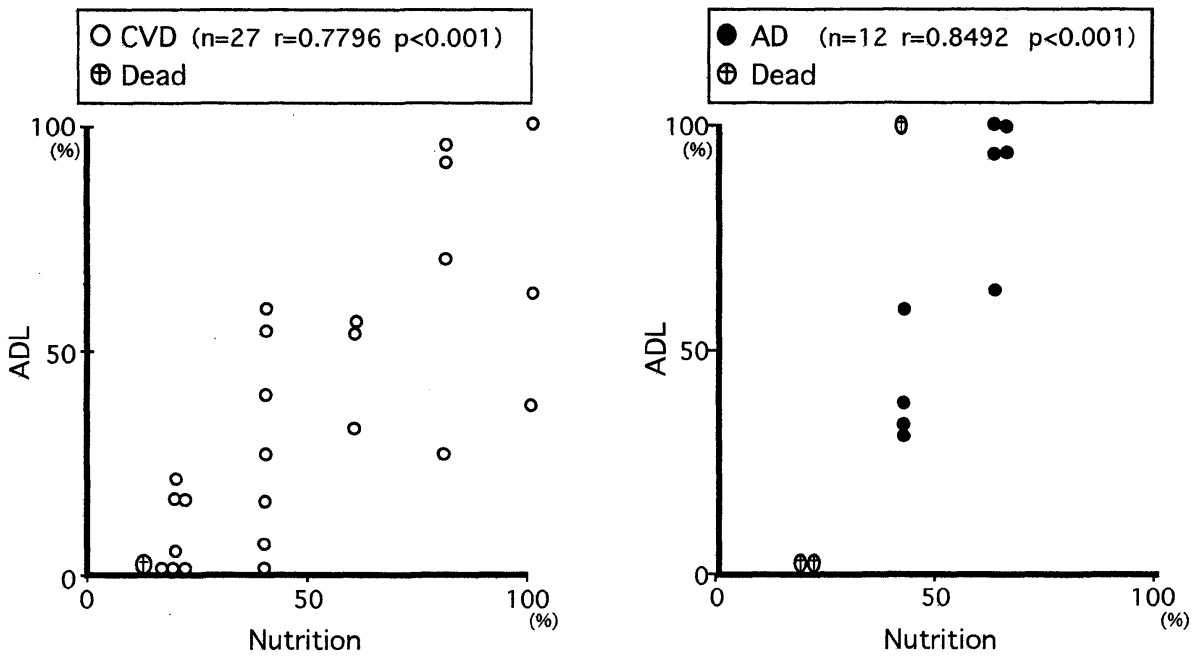

Fig. 3 Relations between Nutritional State and Activity of Daily Living (ADL) in Patients with Cerebrovascular Disease (CVD) or Alzheimer's Disease (AD)
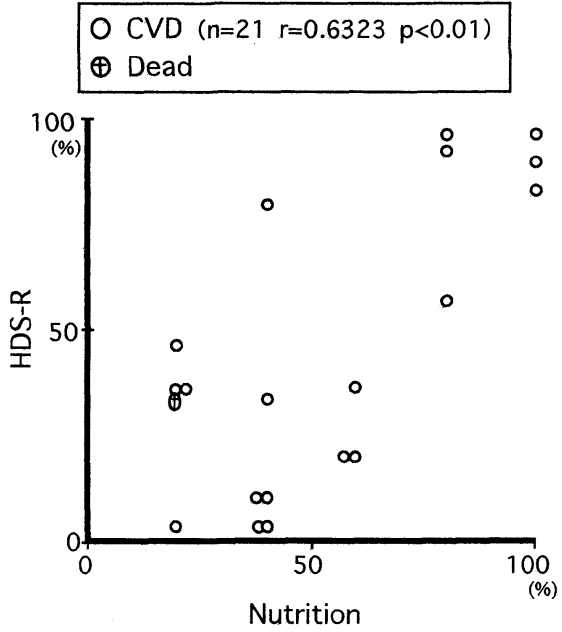

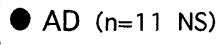

$\oplus$ Dead

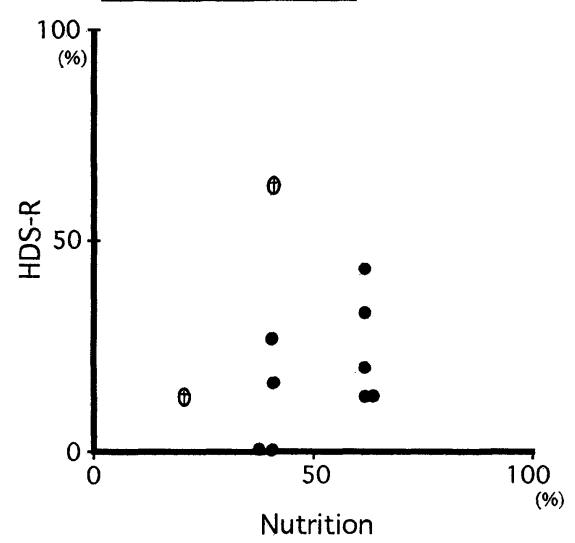

Fig. 4 Relations between Nutritional State and Hasegawa's Dementia Scale (HDS-R) in Patients with Cerebrovascular Disease (CVD) or Alzheimer's Disease (AD)

CVD では，HDS-R と ADL は有意の正相関を示すが, $\mathrm{AD}$ では傾向にとどまり有意ではなかった。このことは $\mathrm{AD}$ の場合, 知的能力の低下があっても身体能力の低下 がそれほどではなく，徘䧃などの異常行動があると介護 上の困難性を増大させる一要因であることを示唆するも のである.

4）栄養と身体・知的機能との関係 (Fig. 3, 4)

CVD では Nutrition と ADL, HDS-R 三因子間に有意 の正相関を認めたが，ADでは Nutritionと ADL 間に のみ正相関を認めた。

5）社会背景と身体・知的機能との関係（Fig. 5,6）

今回我々が用いた社会背景因子のスコアでは, CVD, $\mathrm{AD}$ 共に一定の関係は何も認められなかった。患者をと
りまく家族状況も含めて，社会背景因子として介護力の 強さをスケール化する事の困難性を示すものといえよ う.

6）罹病期間と身体・知的機能との関係 (Fig. 7,8)

䍜病期間と ADL，HDS-R との関連では，唯一AD に おいて罹病期間と HDS-R との間に有意の負の相関を認 めた.

\section{考察}

「少子高齢社会」を迎えて老年者医療の在り方につい ての議論が多方面からなされているが, 老年医学の見地 から論じられたものは本邦では未だ少ない.CGAの必 要性についても本邦では欧米に比べ，かなりの立ち遅れ 

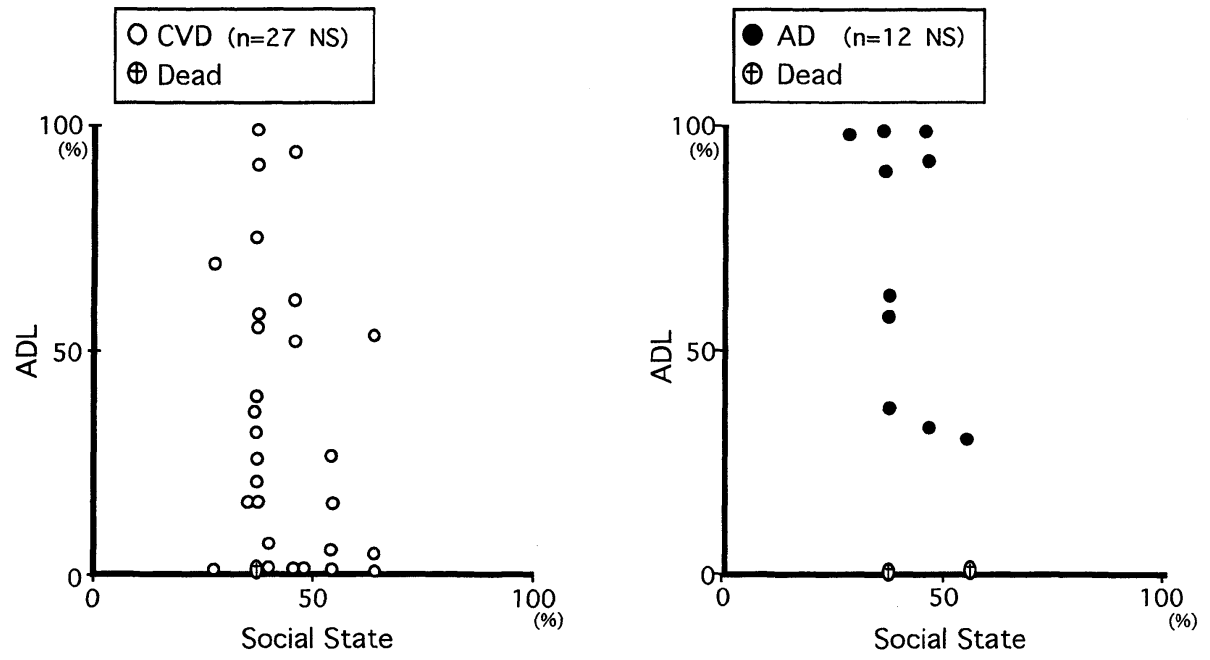

Fig. 5 Relations etween Social State and Activity of Daily Living (ADL) in Patients with Cerebrovascular Disease (CVD) or Alzheimer's Disease (AD)
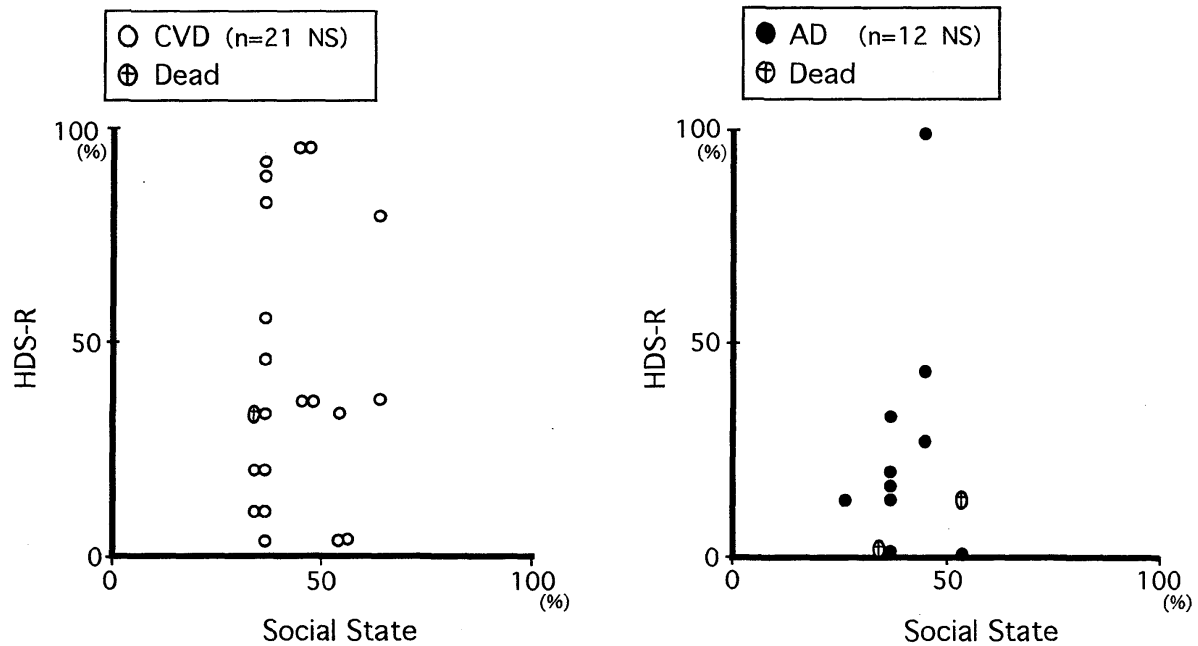

Fig. 6 Relations between Social State and Hasegawa's Dementia Scale (HDS-R) in Patients with Cerebrovascular Disease (CVD) or Alzheimer's Disease (AD)

があり，小澤らが先駆的に総説を発表し78)，また実践の 報告と有用性につき論じてはいるが910)，現実の老年者 医療の現場に，その医学的重要性と評価が十分に浸透し ているとは言い難いのが現状であろう。それ故 CGAを 実践するにあたり有用性を吟味する場合，今の所欧米か らなされた報告を参考にせざるを得ないが，それらの臨 床報告も有用性の有無につき相反する報告もあり，また 有用性ありとしてもその理由，何が原因であったかにつ いては必ずしも説明が十分ではな(2)111 13). 当院でも 1994年以来，看護・介護を中心とした視点から MDSを 採用し，ケアプランの作成とその質の向上を期待してア セスメントを継続実践しているが，実際の作業にあたっ ては，どうしても看護職が中心となりがちで，その他の
医師，リハビリ職，栄養士，ケアワーカー等の参加が必 ずしも十分とはいえないのが現実である．本来看護・介 護も医療の一部ではあるが, 質の高いチーム医療が必要 とされる老人医療の現場においては，各医療スタッフの 職能を生かしたアセスメントとそれらを総合的に結びっ ける医療チームの体制づくりも，CGA が有用性を発揮 できるかどうかの分かれ目であることを痛感させられる と共に，CGA の内容も固定的，普遍的にとらえるべき ではなく，種々な CGAの工夫と試みとが必要とされる であろう，そして CGAの意図するもので中心的に位置 づけられるべき課題は，対象となる症例の「生命および 生活の予後を予測する精度が向上することと, 生活の質 の選択肢の多様化への対応が可能となる」情報が CGA 

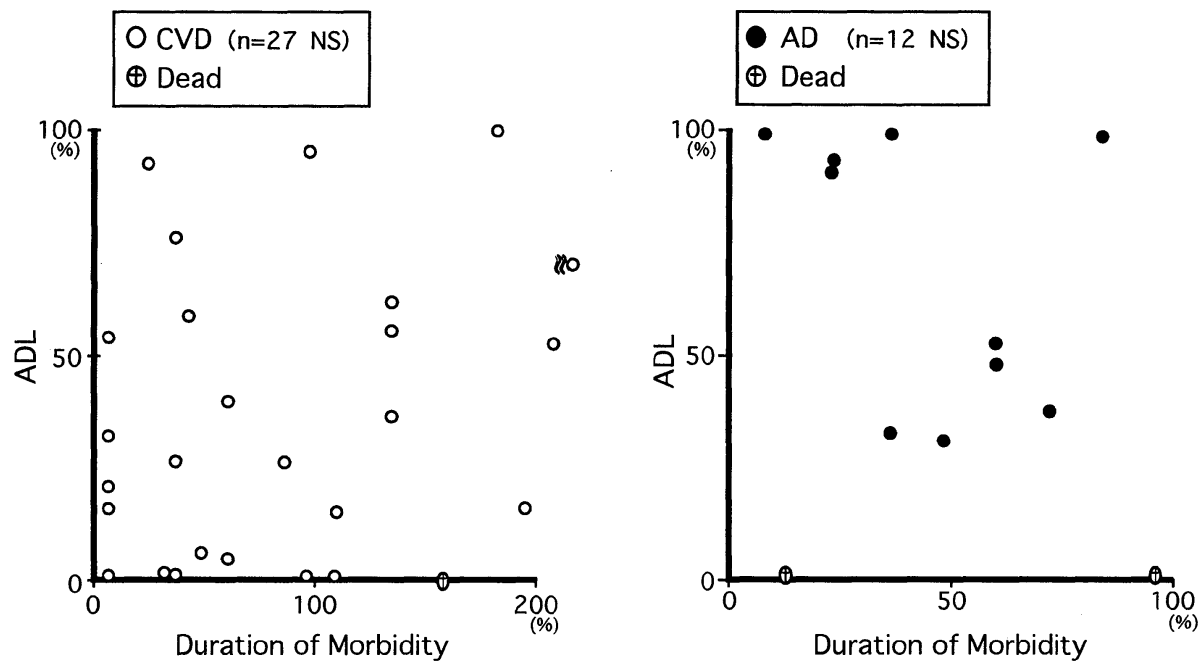

Fig. 7 Relations between Duration of Morbidity and Activity of Daily Living (ADL) in Patients with Cerebrovascular Disease (CVD) or Alzheimer's Disease (AD)
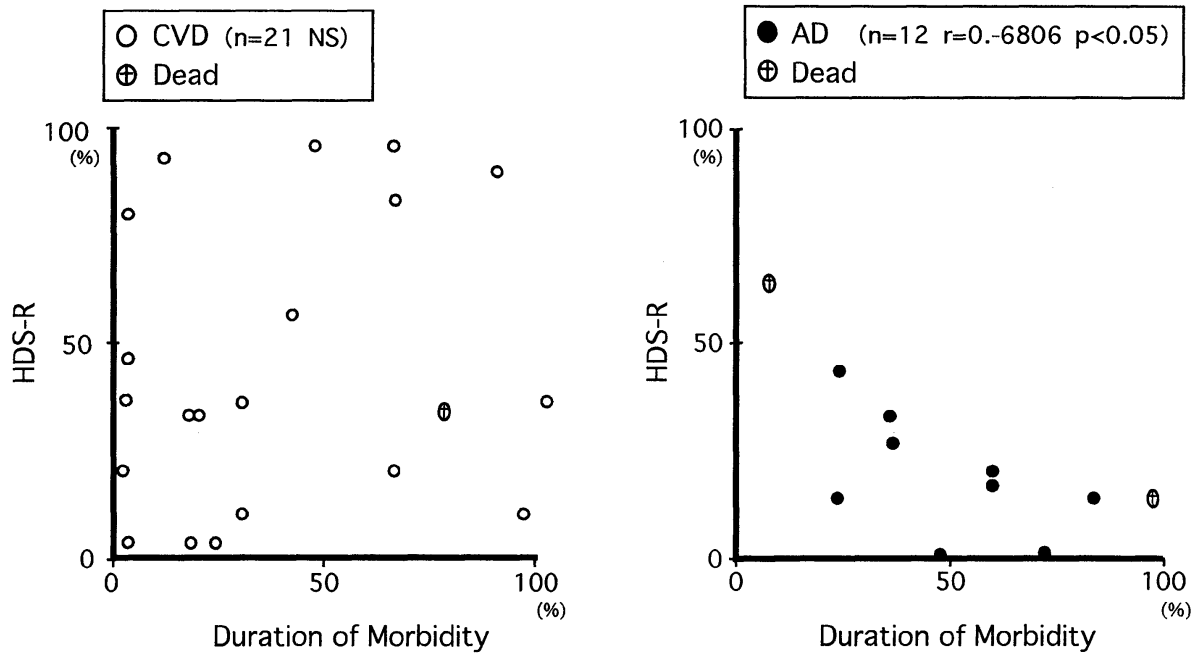

Fig. 8 Relations between Duration of Morbidity and Hasegawa's Dementia Scale (HDS-R) in Patients with Cerebrovascular Disease (CVD) or Alzhimer's Disease (AD)

実践の結果得られるかどうかであろうと考えられる，今 回医師の立場から, 病態の特色把握も一つの視点として 加え, スコア化すると同時に, 医師以外の医療スタッフ の誰が見ても, 対象となる症例の全体像が把握できるこ とを目的にビジュアル面を重視したレーダーチャート方 式を採用し, 用いた指標をスケール化し, 統計的に処理 可能な CGA 作成の一試みについて発表した。今回本法 を用いた調查研究は, まず, 主要診断別の例数が少ない こと. 主要診断そのものの重症度を含めた層別化が不十 分であること. 合併症, 動脈硬化危険因子の評価に関し ても，重症度などを考慮に入れた重みづけが十分に検討 されていないスコア化であること，そして更には断面調 査にしかすぎないことなど, 改善, 検討の余地は多々あ
ることは否定できない限界として明らかである。しかし ながら，それらの限界は今後への課題としつつも，今回 の検討から以下の結論が導かれ, 本法の有用性が示唆さ れたものと考える。

（1）レーダーチャート方式による CGA は，要介護老 年者個々人の全体像を医療スタッフ全員が容易に理解し 把握するのに有用であると同時に，各主要診断別病態を パターンで認識するためにも有用であると思われた。

(2) CVDにおいてはADL，HDS-R，Nutritionの三 因子間相互に有意の正相関を認め, 治療・看護・介護の リハビリプラン作成上，これら三つの因子に対して，よ り総合的に戦略を立てる必要性のあることが示唆され た。 
（3）ADにおいては CVD と異なり, ADL と Nutrition 間のみに正相関を認め, HDS-R は唯一罹病期間との間 に負の相関を認めた．現在積極的治療方法のない本症患 者では，HDS-R と罹病期間相互の関連を念頭に，その QOLに重点をおいたケアプラン作成が重要課題と思わ れる.

（4）後期老年者あるいは超老年者においては身体，精 神機能に対するケアと同等かそれ以上に, 栄養学的評価 とそれに基づく栄養ケアの重要性が示唆された。

（5）今後症例数を増加し，その他の主要診断について も病態の特色を明らかにし, 更に時系列的フォローと検 討も加え，本法の有用性を継続検討したい.

本論文の要旨は第40回日本老年医学会総会にて発表した.

\section{文献}

1) AGS Public Policy Commitee: Comprehensive Geriatric Assessment. J Am Geriatric Soc 1989 ; 37 : 437-474.

2) Stuck AE, et al. : Comprehensive Geriatric Assessment: a metaanalysis of controlled trials. Lancet $1993 ; 342$ : 1032-1036.

3）厚生省老人保健福祉局監修：高令者ケアプラン策定指
針. 厚生科学研究所, 1996.

4）加藤伸司ほか：改訂長谷川式簡易知能スケール (HDS-R) の作成. 老年精神医学雑誌 $1991 ; 2(11) ： 1339-1347$.

5) Mahony FI, Barthel DW: Functional evaluation: The Barthel Index. Maryland State Med J $1965 ; 14: 61-65$.

6）奥川幸子：MSW からみた総合的機能評価. Gerontology $1996 ; 8(2): 41-47$.

7）小澤利男：概説一老年医学的総合評価法について. Geriatric Med $1994 ; 32(5): 509-515$.

8）小澤利男：高齢者の総合機能評価. 日老医誌 $1998 ; 35$ (1) $: 1-9$.

9）山中崇他：老人専門病院における総合的機能評価法の試 み. 日老医誌 $1997 ; 34(4): 278-284$.

10）中原賢一ほか：総合機能評価を用いたチーム医療によ り，容態の改善を見た慢性うっ血性心不全の 1 例. 1997; 34(12) : 1023-1027.

11) Rubenstein $\mathrm{LZ}:$ Effectiveness of a geriatric evaluation unit. A randomized clinical trial. N Engl J Med 1984; $311: 1664-1670$.

12) Applegate WB, et al. : A randomized, controlled trial of a geriatric assessment unit in a community rehabilitation hospital. N Engl J Med 1990 ; 322 : 1572-1578.

13) Reuben DB, et al. : A randomized trial of comprehensive geriatric assessment in the care of hospitalized patients. N Engl J Med 1995; 332: 1345-1350.

Abstract

\section{The Radar Chart Method and Its Analysis as a Comprehensive Geriatric Assessment System for Elderly Disabled Patients}

\section{Yoshimori Minemawari and Takamasa Kato}

In order to simply express the results of comprehensive geriatric assessment (CGA) for elderly disabled patients, we tried to develop a CGA system using a radar chart method in 50 patients (age 73 101, mean 85 \pm .4) admitted to our hospital during May 1997. Our clinical database for CGA included 7 major factors (diagnosis, mental function, physical function, nutritional state, complication, coronary risk factors, social background). Finally, the radar chart was made from the results of 6 scored factors other than diagnosis and the correlation was examined statistically between these factors. This study suggests that ; (1) the radar chart method display of CGA is useful for all medical staff to understand the results of CGA for elderly disabled patients and the characteristic patterns of each disease, (2) because significant positive correlations were found between 3 factors (mental, physical, nutritional) in patients with cerebrovascular disease (CVD), a more global strategy for medical care planning, especially for treatment, nursing care and rehabilitation program is necessary in patients with CVD, (3) in patients with Alzheimer's disease (AD), significant positive correlation was found only between physical and nutritional factors; mental factors showed significant negative correlation only with the duration of morbidity and as a result, quality of life is a more important problem for planning care of patients with $\mathrm{AD}$, (4) for elderly disabled patients, nutritional assessment and nutritional care planning are very important as well as mental and physical care planning.

Key words : Comprehensive geriatric assessment, Radar chart, Cerebrovascular disease, Alzheimer' s disease, Nutritional care (Jpn J Geriat $1999 ; 36$ : 206-212) 